\title{
Do precipitation and food affect the reproduction of brown brocket deer Mazama gouazoubira (G. Fischer 1814) in conditions of semi-captivity?
}

\author{
JUAN P. JULIÁ ${ }^{1}$ and SALVADOR J. PERIS ${ }^{2}$ \\ ${ }^{1}$ Reserva Experimental de Horco Molle, Facultad de Ciencias Naturales e Instituto Miguel Lillo, 4300 Tucumán, Argentina \\ ${ }^{2}$ Departamento de Zoología, Facultad de Biología, Universidad de Salamanca \\ Campus Miguel de Unamuno s/n, 37071 Salamanca, Spain \\ Manuscript received on September 3, 2008; accepted for publication on February 9, 2010
}

\begin{abstract}
The births of brown brocket deer (Mazama gouazoubira) in a secondary lower montane forest called "yunga" in northwestern Argentina were compared with rainfall. Analyses were performed with rainfall and flower-fruit fall in an attempt to determine the possible importance of these seasonal variables in birthing. The births were not directly correlated with rainfall, but rather with the flower and fruit fall of exotic plant species. This may be related to favor the development of fawns, which eat the new and more digestible plant parts, accessible one month after their births. The non-seasonal births observed around the year could be related to the selection by the deer of some plant species that have been introduced into the region (Prunus, Morus and Psidium), have a longer fruiting span than the scarce native plant species.
\end{abstract}

Key words: Argentina, birth phenology, fruit, rainfall.

\section{INTRODUCTION}

The brocket deer species (Mazama spp.) constitute a diversified Neotropical genus with six to eleven species, some of them of recent discovery or classification (Duarte and Merino 1997, Geist 1998, Medellín et al. 1998, Putman 1988, Weber and González 2003). The taxonomic value of the genus is also in doubt, since it could be polyphyletic and in fact a species, M. americana, is closer to the genus Odocoileus than to other Mazama species (Gilbert et al. 2006). Despite the broad distribution and apparent abundance of some species of brocket deer, most of their biology, including their reproductive cycle, remains obscure, although the latter is considered to be not seasonal since it lives in the tropics, with few seasonal climatic changes (Barrette 1987). Although birth synchrony in ruminants could be elicited

Correspondence to: Salvador J. Peris

E-mail: peris@usal.es by anti-predator strategies and food availability, seasonal patterns in climate tend to be one of the main issues accounting for the variance in ruminant birth-season length. In any case, according to Rutberg (1987) tropical and subtropical species of deer may give birth at any time of the year, showing only weak breeding peaks.

Some details are known about the reproduction of the red brocket deer Mazama americana (Erxleben 1777). This species reproduces along the year, although there seems to be a more marked concentration of births in the months considered to be most favorable for the development of fawns (Branan and Marchinton 1987). Thus, in Venezuela, fawns are most frequently observed during the periods of the year with the lowest rainfall (Bisbal 1994). In Peru, Gardner (1971) described the mating period of red brocket deer as occurring between July and September, coinciding with the dry season, while births occurred between February and April. Red 
brocket deer is also relatively seasonal in Surinam, where births are concentrated between September and April, in the first - and more moderate - of the two periods of annual rains in the region (Branan and Marchinton 1987). In the Misiones province (Argentina), red brockets reproduce with greatest frequency between $\mathrm{Au}$ gust and October (Crespo 1982). In contracts, in northeastern Peru, the species did not show reproductive seasonality (Hurtado-González and Bodmer 2006). Macnamara and Eldridge (1987) observed that in captivity the red brocket reproduces at the same rate through the year.

Less is known about the reproductive biology of the brown brocket M. gouazoubira (G. Fischer 1814), (Richard and Juliá 2001a). However, in wild may show birth peaks (Stallings 1986, Frädrich 1987, Bisbal 1994). Also, as M. gouazoubira is a polyphletic species (Weber and González 2003, Hassanin pers. com.), the different papers on its reproduction could also refer to different species.

Few data are available about the reproduction of the deer in subtropical forests, such as those located at the southern limits of its distribution, like the premontane forest in northwest Argentina. This eco-region has a seasonal climate, with a dry season in which the decidous trees lose their leaves (Prado 1995), and these variations could influence the reproduction strategy of the deer (Richard et al. 1995a). Although brocket deer forage on about 75 plant species, they prefer only a few of them (Richard and Juliá 2001b). Since the reproductive parts of plants (flowers, fruits and seeds) are an important, although seasonal, resource in the diet of brown brocket deer, with up to $68 \%$ of the diet (Gayot et al. 2004), we tested for possible correlations between the availability of the most important flowers and fruits in the deer diet and the births of fawns. Currently, these select items come from four exotic species that are very palatable to the deer and over the last 50 years became widely distributed on the lower slopes of the San Javier hills: namely, peach (Prunus persica), mulberry (Morus alba and M. nigra) and guava (Psidium guajava). The present study analyses the reproductive data of the species in a relative human modified subtropical seasonal forest, with two variables - local rainfall and consumption of fruit by the deer - that may influence its reproductive strategy.

\section{MATERIALS AND METHODS}

The study was carried out at the Reserva Experimental Horco Molle (REHM), a protected area supervised by the Faculty of Natural Sciences and the Miguel Lillo Institute of the National University of Tucumán, Argentina (Richard 2000). It is located on the eastern slopes of the San Javier hills $\left(26^{\circ} 38^{\prime}-26^{\circ} 57^{\prime} \mathrm{S}\right.$ to $65^{\circ} 26^{\prime}$ $65^{\circ} 20^{\prime} \mathrm{W}$ ) in the province of Tucumán (northwest Argentina). Mean annual rainfall in the zone is about $1313 \mathrm{~mm}$. The study area has a dry season, with less than $75 \mathrm{~mm} / \mathrm{month}$ on average, that extends from May to October, and a rainy and hot season between November and April, with more than $95 \mathrm{~mm} /$ month of average rainfall. The original premontane forest vegetation has been strongly altered, and the vegetation now comprises pastures, shrub and secondary forests (Aceñolaza 1989). In 1988, six brown brocket deer were confined in an enclosure of around 18 ha with the same natural vegetation as on the lower slopes of the San Javier hills, located near the study area. The species is common in the REHM outside the enclosure. The origin of the research individuals come from the surroundings hills (2) and the rest of the herd, from a Chaco forest of Santiago del Estero province. Both, Chaco and premontane forests show seasonality, although the last is a drier region. In spite of the long study period, the enclosure, although large enough ( $>25 \mathrm{ha}$ ) and with habitat similar to its surroundings (including vegetation and occasional predation by ocelot (Felis pardalis), the mixed stock origin of the animals could affect some of the data interpretation. The number of deer in the area fluctuated from eight to 16 individuals during the 14 years of the study, with an average between 10 to 14 animals (on average there were only 2-3 males at the same time). Data were obtained daily by wardens and the authors from September 1988 to June 2001, and sampling was performed throughout the enclosure, following marked routes. Sampling units were the direct observation of births, fawns, or the mothers with their fawns. Three miscarriages were observed (Juliá and Richard 2001), and their estimated dates of birth were added to the data. The dates of birth of the fawns were estimated as from one month of age and recorded according to their size, "hider type" behaviour (Lent 1972) and skin color pattern (Richard et al. 1995b). When the age of the fawns 
could not be determined, such observations were discarded. Births were ordered by month and possible conceptions were estimated on the basis of the period of gestation of the species, which is around 7 months (Barrette 1987).

The only seasonal variables considered were rainfall and the availability of palatable fruits for deer and the fall of flowers (mulberry) (Richard and Juliá 2001b).

The importance of the plants as food was calculated from 1991 to 1995 , following direct observations 4-6 hours per day and 3-5 days per week. Deer were observed at a distance of 3 to $10 \mathrm{~m}$, which permits identification of the plants and their parts consumed, and the proportion of fruits and other plant pants in diet were estimated by direct observation (Richard and Juliá 2001b). The observations were established by combining the presence/absence of fallen flowers/fruits under trees from a sample of 6 peach, 10 guava and $10 \mathrm{mul}-$ berry trees and the percentage of these fruits in the diet of the deer. We established an estimator that combined the presence of food - the proportion of samples $(n=$ 840) with fallen fruit or flowers - and its importance in the diet by ranks. These were: $0=$ almost complete absence of fallen flowers and fruits and importance in the diet of less than $1 \% ; 1=$ low availability flowers and fruits $(10 / 15 \%$ of the sample and importance in the diet from $1-10 \%) ; 2=$ medium availability flowers and fruits (more than $20 \%$ and less than $50 \%$ of the samples) and importance in the diet between 11 and 20\%; 3 = medium-high availability flowers and fruits (51$100 \%$ of the samples) and importance in the diet greater than $20 \%$.

Monthly rainfall data, obtained from a local station, were from 1978 onwards (Ortiz pers. comm). A MannWhitney $U$-test was performed to determine whether there were significant differences between the number of births per month in the dry and rainy seasons. The Spearman correlation test evaluated the relationship between rainfall and births and between the presence and consumption of flowers/fruits and fawn births.

\section{RESULTS}

A total of 23 births of confirmed dates were recorded from September 1988 to October 2001. All parturitions afforded a single fawn and no twins were seen. No significant difference was observed in the birth rate between the dry and rainy seasons (Mann-Whitney $U$-test $=8.5$ ), and although $65 \%$ of the births appeared to be concentrated within the rainy season (Fig. 1), no statistical correlation was obtained between births and rainfall $\left(r_{s}=0.407\right.$, d.f. $\left.=12\right)$. However, it is important to point a significant correlation observed between the average rainfall and the births of the previous month $\left(r_{s}=\right.$ $0.711 \leq 0.02$, d.f. $=12$ ) (Fig. 1). Also, the statistical relationship between the births of fawns and the consumption by deer of the plant reproductive parts (flowerfruits) was highly significant $\left(r_{s}=0.706 \leq 0.01\right.$, d.f. $=$ 12) (Fig. 2). The fawns began to eat small amounts of solid matter around the first week of life, but they did not begin to forage with their mothers until they are one month old. The months with the greatest availability of exotic fallen fruits were September, October, November, January, March and April.

\section{DISCUSSION}

According to the data obtained here, the brockets seems to reproduce with some slight peaks in the year, as reported for Venezuela (Bisbal 1994) and Bolivian Chaco (Noss et al. 2003), but in contrast with the Peruvian Amazon (Hurtado-Gonzáles and Bodmer 2006). Births have been observed throughout the year in habitats with a certain degree of climatic seasonality, such as the Paraguayan Chaco (Stallings 1986) and brocket deer in captivity in temperate regions (Frädrich 1987). Anyway, it is important to keep in mind that if M. gouazoubira is a poliphyletic species, those data could refer to different species. In any case, the length of the breeding season in most mammal species, from rodents to elephants, is affected by population density, with an extended period at low densities (Delany 1982). The density in the study area was very high in comparison with the maximum natural population, estimated at up to 12.55 brockets $/ \mathrm{km}^{2}$ (Ayala and Noss 2000). It is difficult to establish whether population density influenced the breeding season of brocket deer because other factors such as climate, the sex-ratio and sexual segregation, the mating system, dispersal, home-range size and the food supply interact with one another in complex ways (Durant 2000). 


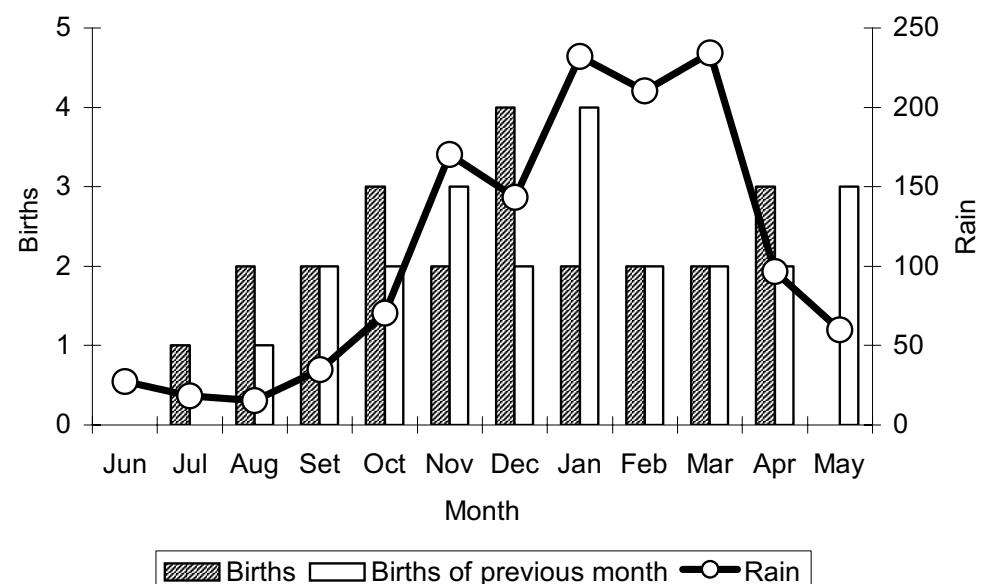

Fig. 1 - Monthly precipitation compared with births in the previous month of M. gouazoubira in the Horco Molle Experimental Reserve-REHM from September 1988 to June 2001.

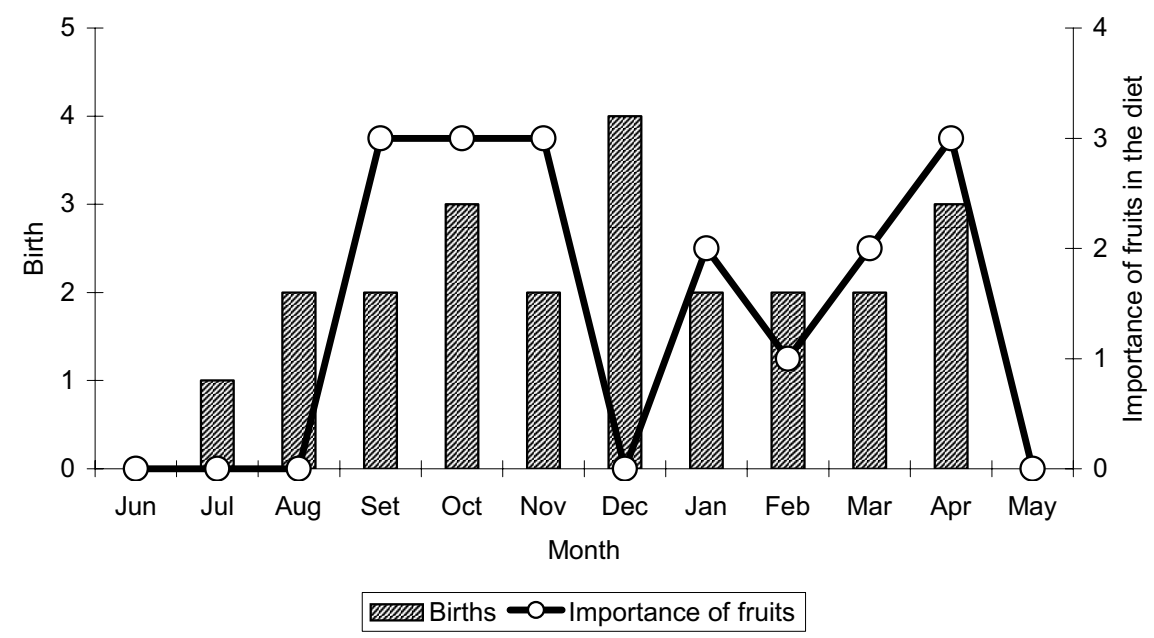

Fig. 2 - Importance of fruit in the diet and births of M. gouazoubira from 1988 to 2001.

The dispersion of deer births over the year could be related in tropics with variability in rainfall between years, with peaks of births in those seasons with relatively better climatic conditions (Branan and Marchinton 1987, Bisbal 1994). However, no statistical analysis was performed by the last authors to sustain their comments. Slight birth peaks were observed in the REHM, although these could not be directly correlated statistically with precipitation, a significant correlation was observed between previous month average rainfall and births (Fig. 1). Also, there was a positive correlation between the abundance and availability of reproductive parts of the plants and births (Fig. 2). In other words, rain and fructification influence the reproduction seasonality of brown brocket deer in the study area.

When available, the reproductive parts of plants (fruits, seeds, and to a lesser extent flowers) are some of the main components in the diet of brocket deer in Peru (Bodmer 1989), Surinam (Branan et al. 1985), French Guiana (Gayot et al. 2004) and at the REHM (Richard et al. 1995a). The arrival of the rains in the study area coincided with the fall of the most impor- 
tant fruits in the diet of the brocket (Morus spp), but also with the beginning of the period of greatest availability of young green shoots (Richard et al. 1995a). According to Demment and Van Soest (1985), small ungulates such as Mazama have poor efficiency in the digestion of fruits and mainly derive their nutritional uptake from seeds (Bodmer 1989). The birth of fawns in the rainy season could be advantageous for the mother, since they would have a greater quantity and quality of food (flowers, fruits and young green parts), appropriate for lactation. Additionally, the availability of forage for the fawns would accelerate their weaning.

Fawns are born one month before the beginning of the periods of greatest availability of fruit, shoots, and young leaves, thus fawns have a readily digestible and available diet one month later, when they begin to feed by themselves. In spite of the exotic nature of the fruit trees which have mostly replaced the natural fruitbearing species in the premontane forest, they fructify in a period similar to that of autochthonous trees. Indeed, indigenous plant species such as Allophylus edulis, Xylosma pubescens, Carica quercifolia, Eugenia pungens, Blepharocalyx gigantea, Cupania vernalis and Phoebe porphyria bear fruits from November to March (Digilio and Legname 1966), coinciding with the rainy season. The fact that $65 \%$ of the births were observed in the rainy season - although not statistically significant - may indicate the natural disposition of the deer to give birth coinciding with the sprouting of native plants. The relatively low availability of these plant species on the low slopes of the San Javier hills, given their strongly modified vegetation over the last 50 years, may hinder the detection of any relationship between flowers and fruits from native plants and deer births. In fact, the longer fructification around the year of exotic plants (from September to April -8 months) as compared with that of native plants, just 5 months (Boletta et al. 1995), underscores the adaptability of the deer to exploit these new and (owing to their availability) more profitable resources. The longer fruiting span in exotic plants could be related to the lengthened breeding season and increased conception rates of the brocket deer in the study area, a modified habitat, showing a possible adaptation of the deer to changes in plant distribution.

\section{ACKNOWLEDGMENTS}

We wish to thank the R.E.H.M. and its former director, E. Richard, for offering access to files and installations, as well as C.P. Juárez, K. García, K. Soria, M. Juárez, M.C. Cocimano, R. Delgado, and I. Palacios for their collaboration. J.P. Juliá acknowledges a Spanish AECI grant. An early draft was improved by the comments of A. Loison and A. Zillikens and three anonymous reviewers.

\section{RESUMO}

Os nascimentos de veados-catingueiros marrons (Mazama gouazoubira) na floresta montana secundária chamada "yunga" no noroeste da Argentina foram comparados com a ocorrência de chuva. As análises foram conduzidas com chuva e com queda de flores e frutos em uma tentativa para determinar a possível importância dessas variáveis com o nascimento destes animais. Os nascimentos não foram diretamente correlacionados com a chuva, mas sim com a queda de flores e frutos das espécies de plantas exóticas. Isto pode estar relacionado ao favorecimento do desenvolvimento de filhotes, que comem as plantas novas e as partes mais digeríveis, que estão acessíveis um mês após seus nascimentos. Os nascimentos não sazonais observados ao longo do ano poderiam estar relacionados com a seleção pelo veado de algumas espécies de plantas que foram introduzidas na região (Prunus, Morus e Psidium), as quais possuem um período frutífero mais longo do que as escassas espécies de plantas nativas da região.

Palavras-chave: Argentina, fenologia de nascimento, fruto, chuva.

\section{REFERENCES}

AceÑolazA PG. 1989. Flora fanerogámica de la Reserva de Flora y Fauna de Horco Molle, Provincia de Tucumán. Serie Monográfica y Didáctica 4: 7-20.

AYAla J AND Noss A. 2000. Censos por transecta en el Chaco Boliviano: limitaciones biológicas y sociales de la metodología. In: CABrera E, Mercolli C AND RESQUIN R (Eds), Manejo de Fauna Silvestre en Amazonía y Latinoamérica. CITES Paraguay, Fundación Moisés Bertoni, University of Florida, Asunción, Paraguay, p. $15-36$.

BARRETTE C. 1987. The comparative behaviour and ecology of chevrotains, musk deer, and morphologically conserva- 
tive deer. In: WEMMER C (Ed), Biology and Management of the Cervidae. Smithsonian Inst Press, Washington DC, London, p. 200-213.

BisBAL FJ. 1994. Biología poblacional del venado matacán (Mazama spp.) (Artiodactyla: Cervidae) en Venezuela. Rev Biol Trop 42: 305-313.

BODMER RE. 1989. Frugivory in Amazonian Artiodactyla: evidence for the evolution of the ruminant stomach. $\mathrm{J}$ Zool 219: 457-467.

Boletta PE, Vides Almonacid R, Figueroa RE And FERNANDEZ MT. 1995. Cambios fenológicos de la selva basal de Yungas en Sierra de San Javier (Tucumán, Argentina) y su relación con la organización estacional de las comunidades de aves. En: Investigación. In: BROWN AD AND GRAU HR (Eds), Conservación y Desarrollo en Selvas Subtropicales de Montaña. Proyecto de desarrollo Agroforestal/LIEY. Tucumán, p. 103-114.

BRANAN WV AND MARCHINTON RL. 1987. Reproductive ecology of white-tailed deer and red brocket deer in Suriname. In: WeMMER C (Ed), Biology and Management of the Cervidae. Smithsonian Inst Press, Washington DC, p. 344-351.

BRANAN WV, WERKHOVEN MC AND MARCHINTON RL. 1985. Food habits of brocket and white-tailed deer in Suriname. J Wildlife Manage 49: 972-976.

CREspo JA. 1982. Ecología de la comunidad de mamíferos del Parque Nacional Iguazú, Misiones. Rev Mus Argentino de Cienc Nat "Bernardino Rivadavia". Ecología 3: 45-162.

Delany MJ. 1982. Mammal Ecology. Blackie, Glasglow, $162 \mathrm{p}$.

Demment MW and VAn Soest PJ. 1985. A nutritional explanation for body-size patterns of ruminant and nonruminant herbivores. American Naturalist 125: 641-672.

Digilio AP AND LEgNAME PR. 1966. Los árboles indígenas de la provincia de Tucumán. Opera Lilloana XV: $1-29$.

Duarte JMB And Merino ML. 1997. Taxonomia e evolução. In: DUARTE JMB (Ed), Biologia e Conservação de Cervídeos Sul-Americanos: Blastoceros, Ozotoceros e Mazama. FUNEP, Jaboticabal, Brasil, p. 2-21.

DURANT S. 2000. Dispersal patterns, social organization and population viability. In: GOSLING G AND SUTHERLAND M (Eds), Behaviour and Conservation. Cambridge University Press, p. 172-197.

FRÄDICH H. 1987. The husbandry of tropical and temperate cervids in the West Berlin Zoo. In: WeMMER C (Ed),
Biology and management of the Cervidae. Smithsonian Inst Press, Washington DC, p. 422-428.

GARDNer AL. 1971. Postpartum estrus in a red brocket deer, Mazama americana, from Peru. J Mammal 52: 623-624.

Gayot M, Henry O, Dubost G and Sabatier D. 2004. Comparative diet of the two forest cervids of the genus Mazama in French Guiana. J Trop Ecol 20: 31-43.

GEIST V. 1998. Deer of the world. Their evolution, behaviour and ecology. Stackpole Books, Pennsylvania, 421 p.

Gilbert CA, Ropiquet And Hassanin A. 2006. Mitochondrial and nuclear phylogenies of Cervidae (Mammalia, Ruminantia): Systematics, morphology, and biogeography. Mol Phylogenet Evol 40: 101-117.

Hurtado-GonzÁlez JL AND Bodmer RE. 2006. Reproductive biology of female Amazonian brocket deer in northeastern Peru. Eur J Wildl Res 52(3): 171-177.

JULIÁ JP AND RICHARD E. 2001. Management of brown brocket deer (Mazama gouazoubira) under conditions of strict control in Reserva Experimental Horco Molle (Tucumán, Argentina). Deer Specialist Group News 16: 8-9.

LENT P. 1972. Mother - infant relationships in ungulates. Behaviour paper 1: 14-55.

MACNAMARA M AND EldRIDGE WD. 1987. Behaviour and reproduction in captive pudu (Pudu puda) and red brocket (Mazama americana), a descriptive and comparative analysis. In: WEMMER C (Ed), Biology and management of the Cervidae. Smithsonian Institute Press, Washington DC, p. 371-387.

Medellín RA, Gardner AL And Aranda JM. 1998. The taxonomic status of the Yucatán brown brocket, Mazama pandora (Mammalia: Cervidae). P Biol Soc Wash 111: 1-14.

Noss AJ, CuÉllar E ANd CuÉllar RL. 2003. Hunter self-monitoring as a basis for biological research: data from the Bolivian Chaco. Mastozoología Neotropical. J Neotrop Mammal 10: 49-67.

PRADO DE. 1995. Selva pedemontana: contexto regional y lista florística de un ecosistema en peligro. In: BROWN AD AND GRAU HR (Eds), Investigación, conservación y desarrollo en selvas subtropicales de montaña. Desarrollo Agroforestal/LIEY - Universidad Nacional de Tucumán, Tucumán, Argentina, p. 19-52.

PUtMAN R. 1988. The natural history of deer. Ithaca, Comstock, $191 \mathrm{p}$.

RICHARD E. 2000. Reserva Experimental Horco Molle. In: Cabrera E, Mercolli C and Resquin R (Eds), Manejo de fauna silvestre en Amazonía y Latinoamérica. 
CITES Paraguay, Fundación Moisés Bertoni, University of Florida, Asunción, Paraguay, p. 249-261.

RICHARD E AND JULIÁ JP. 2001a. Corzuela parda. In: DELLAFIORE CL AND MACEIRA N (Eds), Los ciervos autóctonos de la Argentina. GAC, Buenos Aires, p. 36-46.

Richard E AND Juliá JP. 2001b. Dieta de Mazama gouazoubira (Mammalia, Cervidae) en un ambiente secundario de Yungas, Argentina. Iheringia, Serie Zoología 90: 147-156.

Richard E, Juliá JP AND ACEÑOlaZA P. 1995a. Hábitos frugívoros de la corzuela parda (Mazama gouazoubira, Fischer, 1814) (Mammalia-Cervidae), en un ambiente secundario de Yungas. Doñana Acta Vertebrata 22: 19-28.
Richard E, Juliá JP AND ACEÑOlaza P. 1995b. La corzuela parda. Serie Monográfica y Didáctica 22: 1-35.

RUtBerg AT. 1987. Adaptative hypotheses of birth synchrony in ruminants: an interspecific test. Am Nat 130(5): 692-710.

STALlingS JR. 1986. Notes on the reproductive biology of the grey brocket deer (Mazama gouazoubira) in Paraguay. J Mammal 67: 172-175.

Weber M And GonzÁlez S. 2003. Latin American deer diversity and conservation: a review of status and distribution. Ecoscience 10(4): 443-454. 